\title{
CHANGES IN THE LOWER DRAVA RIVER WATER QUALITY PARAMETERS OVER 24 YEARS
}

\author{
Vlatka GVOZDIĆ ${ }^{1}$, Josip BRANA², Dinko PUNTARIĆ ${ }^{3}$, Domagoj VIDOSAVLJEVIĆ4 \\ and Danijela ROLAND ${ }^{1}$
}

Department of Chemistryl, Department of Physics², University of J. J. Strossmayer, Osijek, Zagreb Public Health Institute, Department of Health Ecology, Zagreb³, Vukovar General Hospital, Vukovar ${ }^{4}$, Croatia

Received in July 2011

CrossChecked in November 2011

Accepted in November 2011

\begin{abstract}
The goal of this study was to analyse 13 physico-chemical and microbiological parameters of the Drava River water at three sampling sites in the lower Drava region (eastern Croatia) over two distinct periods: the pre-war period between 1985 and 1992 and the post-war period between 1993 and 2008. Over both periods, most parameters kept within the tolerable water quality limits, while $\mathrm{NO}_{3}-\mathrm{N}, \mathrm{NH}_{4}-\mathrm{N}$ and $\mathrm{BOD}_{5}$ were higher. The lower Drava showed slight organic pollution with high concentrations of dissolved oxygen. High levels of total coliforms and heterotrophic bacteria in the post-war period were only found downstream of the town of Osijek. Upstream of Osijek, the river showed a tendency for improvement.
\end{abstract}

KEY WORDS: cluster analysis, Drava River, microbiological parameters, organic pollution, physicochemical parameters

The Drava River is an international river, part of which runs through Croatia. The section that runs from Legrad and drains into the Danube is called the Lower Drava. This section has long been a border between Hungary and Croatia and was spared from man-made pollution (1). In fact, it has become a unique oasis of numerous plant and animal species, Kopački Rit Nature Park in particular. However, recent groundwater findings in eastern Croatia point to extremely high concentrations of arsenic of up to $610 \mu \mathrm{g} \mathrm{L} \mathrm{L}^{-1}(2,3)$. Since the late eighties, groundwater has been the main source of drinking water for the population of nearly 200,000 people in this part of Croatia.

Current regulations in Croatia $(4,5)$ divide ground and surface waters in five quality classes. Class I are ground and surface waters that can be used for drinking and in food industry in its natural state or after disinfection, as well for breeding trout. Class II is water that can be used in its natural state for swimming and recreation or can be treated for drinking and other industrial purposes. Class III is water that can be used by industries with no specific water quality requirements and in agriculture. Class IV waters must be treated before any kind of use, where other water supply is not available. Class $\mathrm{V}$ are waters that cannot be used for any purpose.

The goal of the national water protection strategy $(4,5)$ is to keep the Drava River within the Class II limits. Following a purification procedure, it can be used for drinking and in industry.

Water quality of the Drava River is highly influenced by its tributary the Mura River (6), which is classified as Class IV stream by Croatian standards (5). A number of studies have reported improvements in the water quality of the Danube drainage basin over the last two decades (7-11). Vitale et al. (12) claim that the improving trend started in the late 1980s and again in 1995. Since 1991, industrial pollution dropped significantly throughout Croatia, that was hit by war operations, Osijek in particular. 
However, the Drava River is a wastewater recipient for many towns and villages. As these grow, so do the volumes of domestic sewage that are usually rich in biodegradable organic matter and surface runoff. Pathogens from these discharges may pose a risk to downstream water users. Additionally, microorganisms often accumulate in river sediments.

Temporal distribution of pollutant concentrations can be determined either by sampling water at low frequency over a long period of time or at high frequency over one hydrologic cycle (one year) (1, 12). The data analysed in this study were obtained from Hrvatske vode, the national water management agency that is responsible for surface and ground water quality monitoring. Most of the data are from samples collected at weekly intervals. Microbiological parameters were analysed from samples collected at monthly intervals.

The aim of the study was to provide a more comprehensive view of the Drava water pollution over 24 years and see whether war and ensuing economic recession affected it in any way. We also wanted to see if there were differences between measurement sites.

\section{MATERIALS AND METHODS}

\section{Measurement sites}

Monitoring that took place between 1985 and 2008 included three sites: 1) Bistrinci (rural area) at $45^{\circ} 41^{\prime}$ 30" North, 18 23' 55" East; 2) Višnjevac (suburbia upstream of Osijek) at $45^{\circ} 41^{\prime} 30^{\prime \prime}$ North, $18^{\circ} 23^{\prime} 55^{\prime \prime}$ East; and 3) Nemetin (suburbia downstream of Osijek) at $45^{\circ} 32^{\prime} 24^{\prime \prime}$ North, $18^{\circ} 46^{\prime} 25^{\prime \prime}$ East.

The major economic activity in Bistrinci area includes intensive crop and vegetable production, wood processing, and paper industry. The town of Osijek is the biggest urban center in eastern Croatia with a population of 120,000 . The wastewater coming from the city of Osijek and surrounding urban areas is being discharged into the river Drava without being previously treated.

\section{Sampling}

Weekly sample analysis (totalling 940 water samples per site) included temperature, $\mathrm{pH}$, electrical conductivity (EC), dissolved oxygen (DO), oxygen saturation (OS), chemical oxygen demand (COD), total suspended solids (TSS), nitrate nitrogen $\left(\mathrm{NO}_{3}-\mathrm{N}\right)$, nitrite nitrogen $\left(\mathrm{NO}_{2}-\mathrm{N}\right)$, ammonia-nitrogen $\left(\mathrm{NH}_{4}-\mathrm{N}\right)$, and five-day biochemical oxygen demand $\left(\mathrm{BOD}_{5}\right)$.

Monthly samples were taken for microbiological analysis that included total coliforms (TC) and heterotrophic (HE) bacteria (303 samples per site).

Samples were analysed right after collection using ion chromatography to determine the concentrations of $\mathrm{NO}_{3}-\mathrm{N}, \mathrm{NO}_{2}-\mathrm{N}$, and $\mathrm{NH}_{4}-\mathrm{N},(13,14)$ and titration to measure biochemical and chemical oxygen demand $(15,16)$. Total suspended solids were determined gravimetrically (17), while dissolved oxygen, oxygen saturation, electrical conductivity and $\mathrm{pH}$ electrochemically (18-21). Coliform bacteria were isolated on lactose TTC agar and scored using membrane filtration and HE were inoculated on yeast extract agar and determined by colony count $(22,23)$. All the water quality parameters are expressed in mg L ${ }^{-1}$, except $\mathrm{pH}, \mathrm{EC}\left(\mu \mathrm{S} \mathrm{cm}^{-1}\right), \mathrm{T}\left({ }^{\circ} \mathrm{C}\right)$, total coliforms (the most probable number, MPN per 100 $\mathrm{mL}$ ) and heterotrophic bacteria $\left(\mathrm{MPN} \mathrm{mL}^{-1}\right)$.

\section{Statistics}

Statistical analysis of the water quality parameters was performed using the statistical software Statistica, version 7.0. In addition to standard descriptive statistics, we also used cluster analysis (24-26), which was based on recalculated average monthly values of chemical parameters to adjust for microbiological data based on monthly samples. To normalise data using Euclidean distance and to quantify the (dis)similarity between sampling sites, we applied an agglomerative single-linkage algorithm ("nearest neighbours"). The results obtained by hierarchical clustering are presented in the form of dendrograms.

\section{RESULTS AND DISCUSSION}

Here we report the results of a spatial and temporal analysis of 13 chemical, microbiological, and ecological parameters assessed at three sampling sites over 24 years.

Table 1 shows the measured parameters that met Class I or II requirements set by the current national regulation (4). Figures 2 to 6 use box and whiskers plots to show the parameters that did not meet Class I or Class II water quality requirements $\left(\mathrm{BOD}_{5}\right.$, $\mathrm{NO}_{3}-\mathrm{N}, \mathrm{NH}_{4}-\mathrm{N}$, total coliforms, and heterotrophic bacteria, respectively). 
Table 1 Median, range, and the percentile values of the quality parameters for the Drava water

\begin{tabular}{|c|c|c|c|c|c|c|c|c|}
\hline \multirow[t]{2}{*}{ Variable } & \multirow[t]{2}{*}{ Class $^{\#}$} & \multirow[t]{2}{*}{ Values } & \multicolumn{3}{|c|}{$\begin{array}{c}\text { Pre-war } \\
(1985-1992)\end{array}$} & \multicolumn{3}{|c|}{$\begin{array}{c}\text { Post-war } \\
(1993-2008)\end{array}$} \\
\hline & & & Site 1 & Site 2 & Site 3 & Site 1 & Site 2 & Site 3 \\
\hline \multirow{3}{*}{$\mathrm{T} /{ }^{\circ} \mathrm{C}$} & \multirow{3}{*}{$*$} & median & 13 & 14 & 14 & 12 & 12.6 & 13 \\
\hline & & range & -15 to 32 & -13 to 32 & -10 to 32 & -10 to 29 & -9 to 29 & -9 to 31 \\
\hline & & $90^{\text {th }}$ percentile & 22.0 & 23.0 & 23.0 & 22.7 & 22.7 & 24.1 \\
\hline \multirow{3}{*}{$\mathrm{pH}$} & \multirow{3}{*}{ I } & median & 7.7 & 7.7 & 7.7 & 7.9 & 7.9 & 7.9 \\
\hline & & range & 6.9 to 8.1 & 6.9 to 8.1 & 7.1 to 8.1 & 6.9 to 9.5 & 6.9 to 9.6 & 6.9 to 9.2 \\
\hline & & $90^{\text {th }}$ percentile & 7.8 & 7.8 & 7.8 & 8.3 & 8.3 & 8.3 \\
\hline \multirow{3}{*}{$\mathrm{EC} / \mu \mathrm{S} \mathrm{cm}^{-1}$} & \multirow{3}{*}{ I } & median & 319 & 320 & 322 & 323 & 326 & 330 \\
\hline & & range & 200 to 453 & 206 to 468 & 200 to 565 & 190 to 580 & 147 to 681 & 164 to 577 \\
\hline & & $90^{\text {th }}$ percentile & 351 & 351 & 351 & 422 & 434 & 435 \\
\hline \multirow{3}{*}{$\mathrm{TSS} / \mathrm{mg} \mathrm{L}^{-1}$} & \multirow{3}{*}{$*$} & median & 60 & 60 & 60 & 30 & 37 & 40 \\
\hline & & range & 20 to 210 & 20 to 200 & 20 to 160 & 2 to 220 & 2 to 250 & 2 to 182 \\
\hline & & $90^{\text {th }}$ percentile & 70.0 & 80.0 & 70.0 & 66.5 & 80.0 & 90.0 \\
\hline \multirow{3}{*}{$\mathrm{NO}_{2}-\mathrm{N} / \mathrm{mg} \mathrm{L}^{-1}$} & \multirow{3}{*}{ II } & median & 0.010 & 0.010 & 0.010 & 0.017 & 0.017 & 0.017 \\
\hline & & range & $\begin{array}{c}0.001 \text { to } \\
0.025\end{array}$ & $\begin{array}{c}0.001 \text { to } \\
0.033 \\
\end{array}$ & $\begin{array}{c}0.001 \text { to } \\
0.030\end{array}$ & 0.001 to 0.05 & $\begin{array}{c}0.001 \text { to } \\
0.066\end{array}$ & 0.001 to 0.066 \\
\hline & & $90^{\text {th }}$ percentile & 0.020 & 0.020 & 0.020 & 0.020 & 0.020 & 0.020 \\
\hline \multirow{3}{*}{$\mathrm{DO} / \mathrm{mg} \mathrm{L}^{-1} \mathrm{O}_{2}$} & \multirow{3}{*}{ I } & median & 9.8 & 9.8 & 9.8 & 9.7 & 9.48 & 9.5 \\
\hline & & range & 4.7 to 8.3 & 4.4 to 18.6 & 4.1 to 18.0 & 5.9 to 24.4 & 5.9 to 23.1 & 5.23 to 24.2 \\
\hline & & $10^{\text {th }}$ percentile & 7.5 & 7.5 & 7.4 & 7.6 & 7.5 & 7.4 \\
\hline \multirow{3}{*}{ OS $/ \%$} & \multirow{3}{*}{ II } & median & 92 & 92 & 91.3 & 92.7 & 89.7 & 89.7 \\
\hline & & range & 45 to 178 & 41 to 176 & 38 to 172 & 56 to 254 & 57 to 261 & 36.8 to 249 \\
\hline & & $10^{\text {th }}$ percentile & 70.1 & 70.0 & 70.0 & 71.8 & 70.1 & 70.1 \\
\hline \multirow{3}{*}{$\mathrm{COD} / \mathrm{mgL}^{-1} \mathrm{O}_{2}$} & \multirow{3}{*}{ II } & median & 4.8 & 5 & 5.1 & 3 & 3.2 & 3.4 \\
\hline & & range & 1 to 10 & 1 to 11 & 1.5 to 10.1 & 1.0 to 9.4 & 0.9 to 11.0 & 1.3 to 18.2 \\
\hline & & $90^{\text {th }}$ percentile & 7.0 & 7.3 & 7.6 & 4.3 & 4.8 & 5.3 \\
\hline
\end{tabular}

* not included in classification

Site 1 Bistrinci, Site 2 Višnjevac, Site 3 Nemetin

\#- classes are defined according to the current Croatian regulation (see reference 4)

$T$-temperature

EC-electrical conductivity

TSS - total suspended solids

$\mathrm{NO}_{2}-\mathrm{N}$ - nitrite nitrogen

$\mathrm{DO}$ - dissolved oxygen

OS - oxygen saturation

COD - chemical oxygen demand

To group variables by similarity, we applied the hierachical cluster analysis. Its results are presented in the form of dendrograms in Figures 7 and 8. Preand post-war data cluster analyses show that the relations between parameters changed over time.

We obtained interesting results for parameters measured during the post-war period (Figure 8). Hierachical cluster analysis shows two clusters at higher distances; a single-member cluster corresponding to $\mathrm{TC}_{3}$, and a two-member cluster containing $\mathrm{HE}_{3}$ and $\mathrm{HE}_{2}$. The third multi-member cluster splits at a lower distance into clusters that comprise the remaining variables. The single-member cluster 1 corresponds to total coliform bacteria at sampling site 3 . The subcluster $2 \mathrm{a}$ corresponds to the spatial variation of only heterotrophic bacteria. The clustering of $\mathrm{HE}_{2}$ and $\mathrm{HE}_{3}$ in the separate cluster points to significant differences in HE measurements from sampling site 1. Sub-cluster $2 \mathrm{~b}$ was characterised by closer distances between members.

The clustering of $\mathrm{BOD}_{(1,2,3)}, \mathrm{NH}_{4}-\mathrm{N}_{(1,2,3)}, \mathrm{NO}_{2}-\mathrm{N}_{(1,2,3)}$, $\mathrm{NO}_{3}-\mathrm{N}_{(1,2,3)}$ in the same cluster (Figure 8) reflects stronger correlations between these parameters. In addition, there are no relevant deviations in the levels between the sampling sites. This suggests that Osijek and its wastewaters do not contribute significantly to 


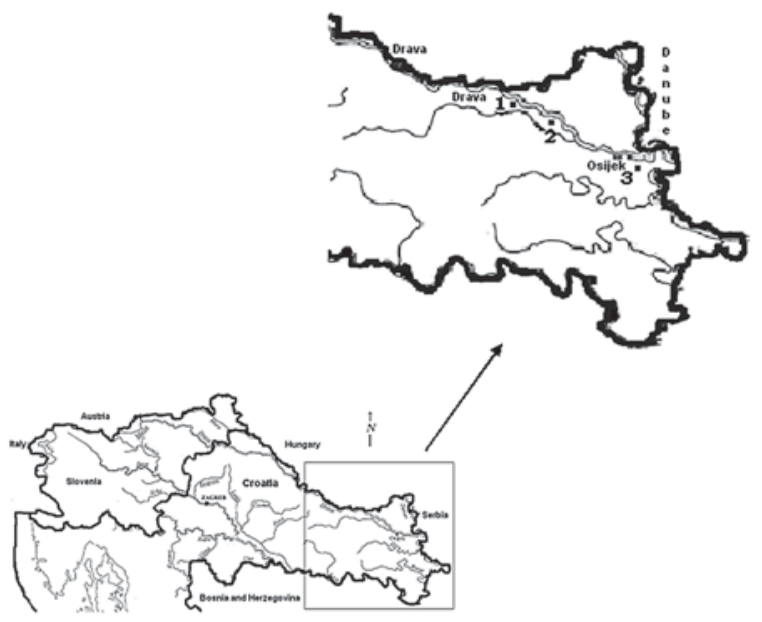

Figure1 Location of the measuring sites

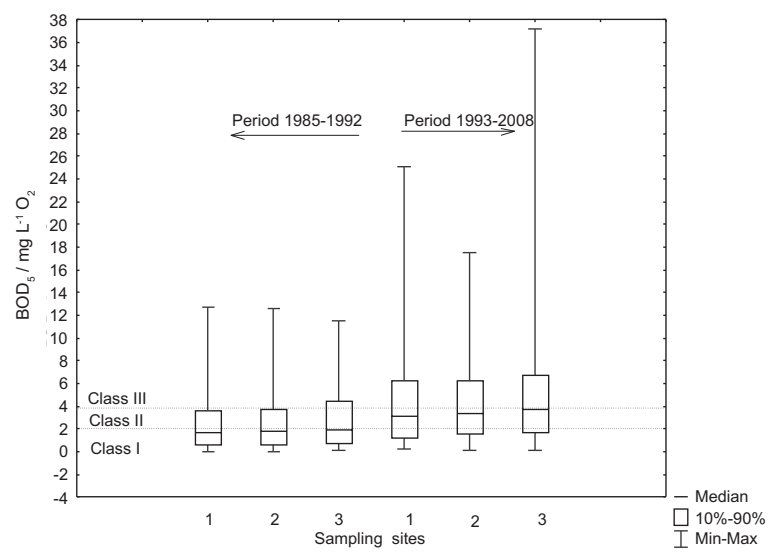

Figure 2 Box and whiskers plots of five-day biochemical oxygen demand $\left(B O D_{5}\right)$

1 - Bistrinci, 2-Višnjevac, 3 - Nemetin

Classes I, II, and III - see definition in the text

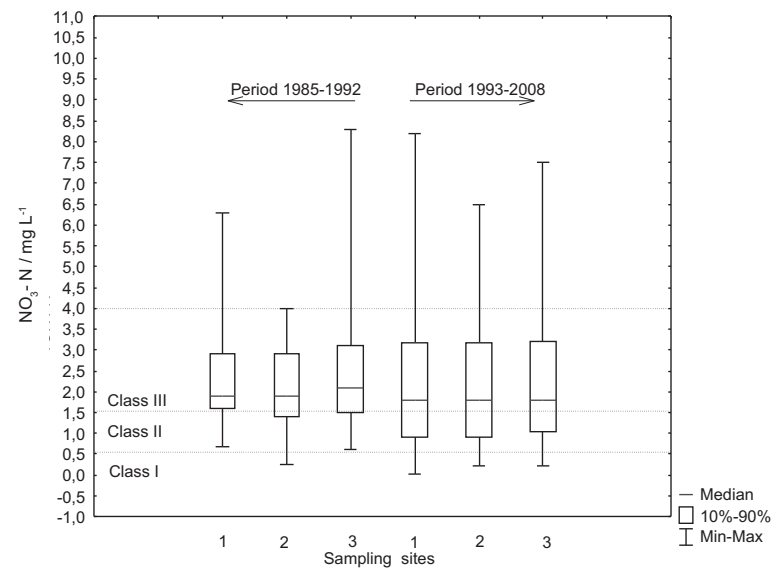

Figure 3 Box and whiskers plots of nitrate nitrogen $\left(\mathrm{NO}_{3}-\mathrm{N}\right)$

1 - Bistrinci, 2 - Višnjevac, 3 - Nemetin. Classes I, II, and III - see definition in the text

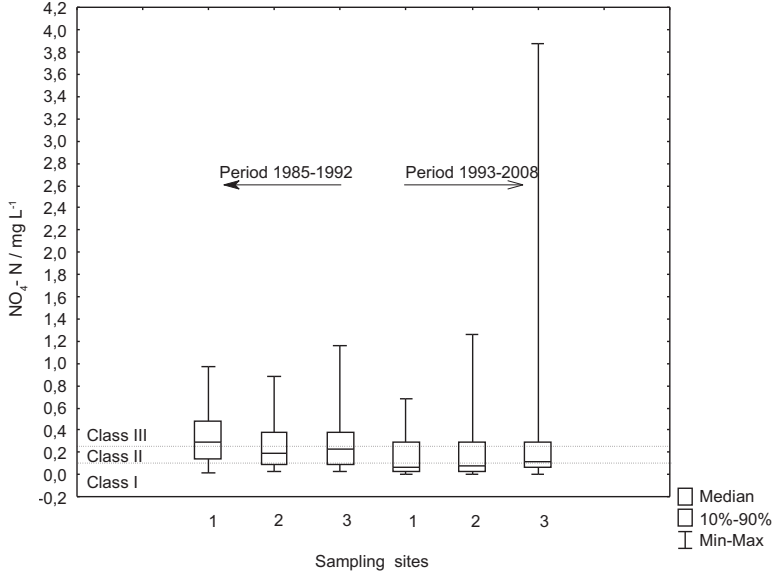

Figure 4 Box and whiskers plots of ammonia-nitrogen $\left(\mathrm{NH}_{4}-\mathrm{N}\right)$

1 - Bistrinci, 2 - Višnjevac, 3 -Nemetin

Classes I, II, and III - see definition in the text

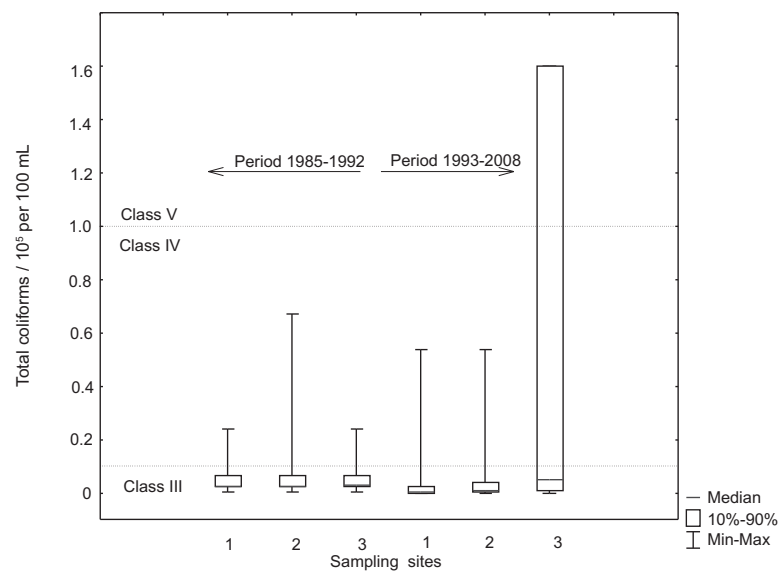

Figure 5 Box and whiskers plots of total coliform bacteria 1 - Bistrinci, 2 - Višnjevac, 3 - Nemetin Classes III, IV, and V-see definition in the text

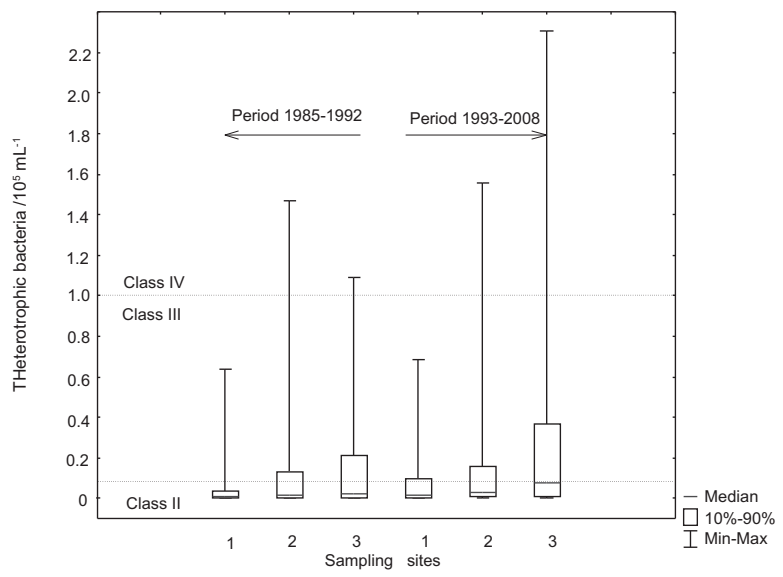

Figure 6 Box and whiskers plots of heterotrophic bacteria 1 - Bistrinci, 2 - Višnjevac, 3 - Nemetin Classes II, III, and IV - see definition in the text 


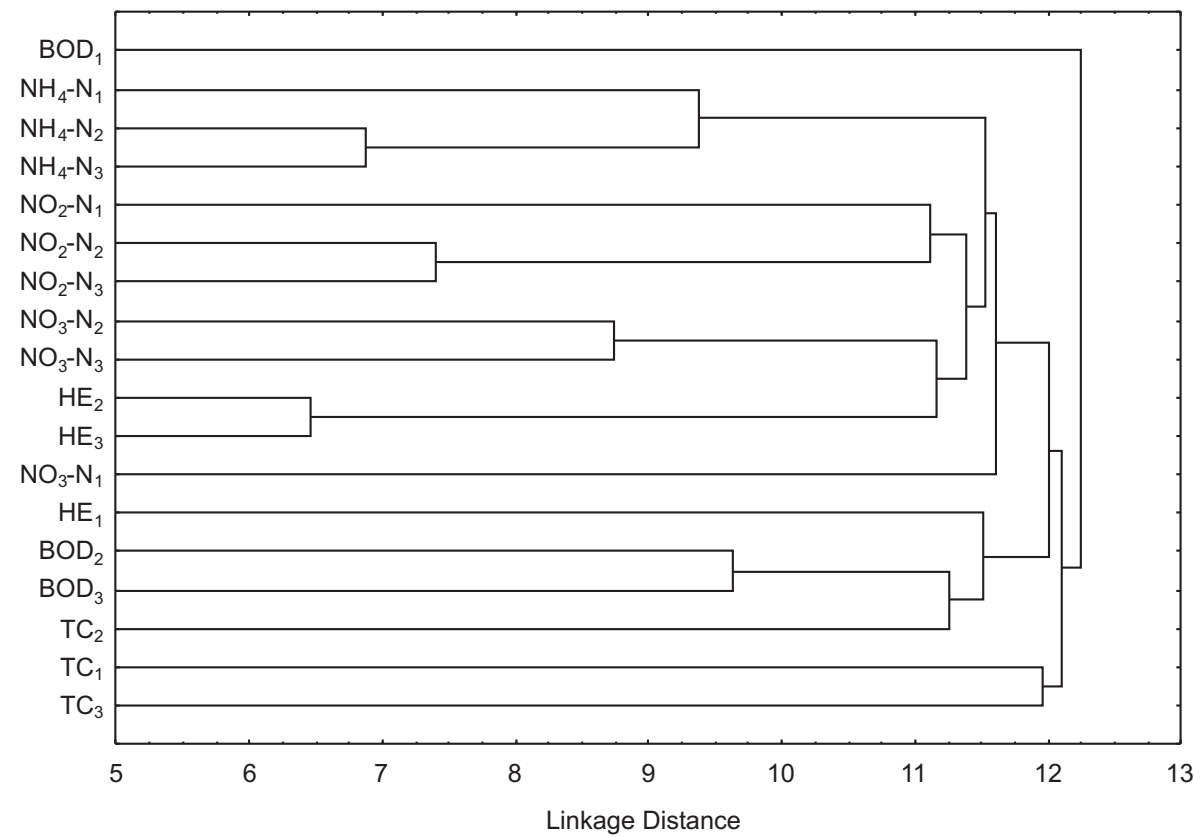

Figure 7 Single linkage clustering (nearest neighbours) of the pre-war water samples using Euclidean distance metrics

Legend:

1 - Bistrinci, 2 - Višnjevac, 3 -Nemetin

TC-total coliforms

$H E$ - heterotrophic bacteria
$B O D_{5}$ - five-day biochemical oxygen demand

$\mathrm{NO}_{3}-\mathrm{N}$ - nitrate nitrogen

$N O-N$ - nitrite nitrogen

$\mathrm{NH}_{4}^{2} \mathrm{~N}$ - ammonia-nitrogen

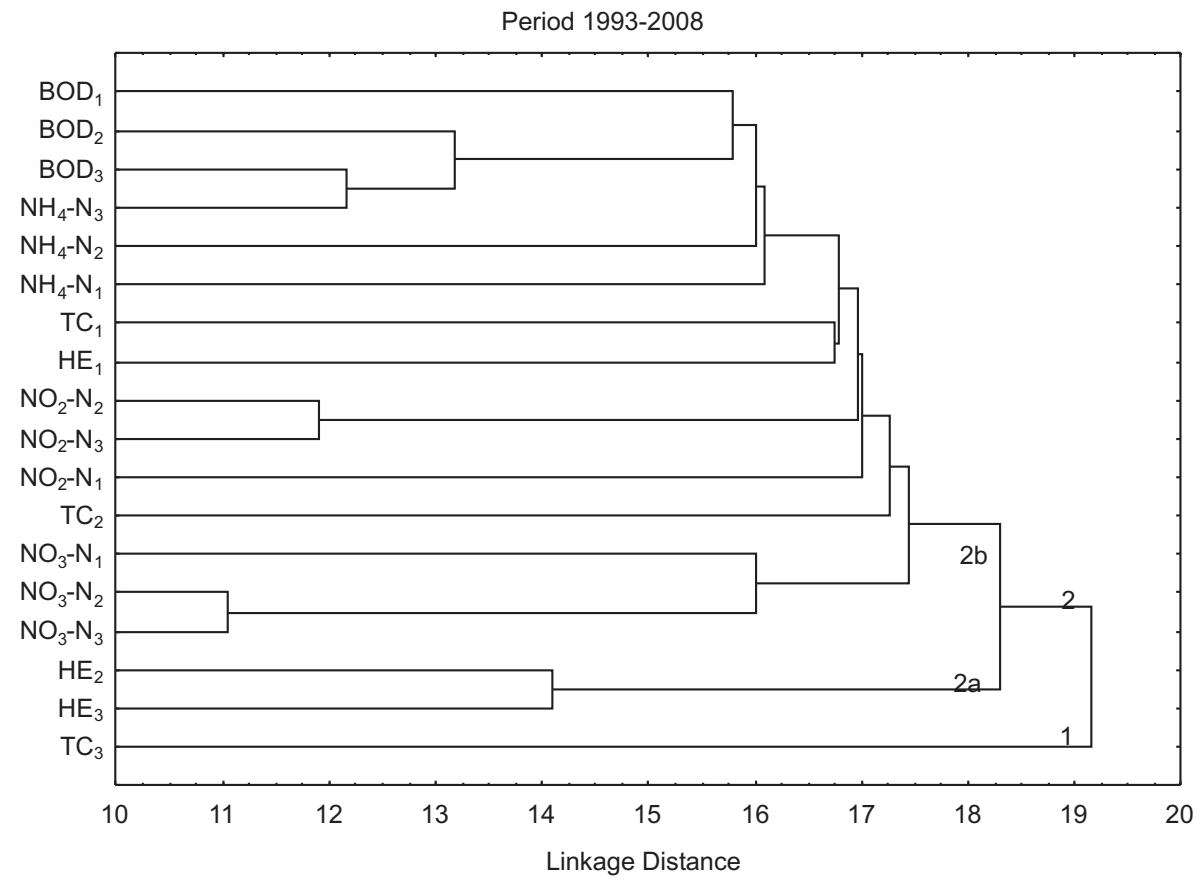

Figure 8 Single linkage clustering (nearest neighbours) of the post-war water samples using Euclidean distance metrics

Legend:

1 - Bistrinci, 2 - Višnjevac, 3 - Nemetin

TC-total coliforms

$H E$ - heterotrophic bacteria
$B O D_{5}$ - five-day biochemical oxygen demand

$\mathrm{NO}_{3}-\mathrm{N}$ - nitrate nitrogen

$\mathrm{NO}, \mathrm{N}$ - nitrite nitrogen

$\mathrm{NH}_{4}^{2} \mathrm{~N}$ - ammonia-nitrogen 
the levels of nutrients and organic matter, but the significant sources are to be found upstream or across the border.

The clustering procedure obtained on the variables measured during pre-war period (Figure 7) highlighted a quite different situation because the measuring stations have more uniform characteristics with respect to all the variables. Here we also briefly discuss the significance of particular physico-chemical parameters of interest. The temperature of running waters of the most of mid, east, and south European rivers varies between $0{ }^{\circ} \mathrm{C}$ and $30{ }^{\circ} \mathrm{C}$. Abnormally high temperatures in river water can arise from thermal discharges, usually from power plants or sewage treatment plants (27). In our study, the temperature of the Drava showed minor temporal and spatial variations.

Another important parameter is $\mathrm{pH}$, as most aquatic organisms are adapted to $\mathrm{pH}$ from 7.2 to 8.7. We found that alkalinity in the Drava river water rose in the post-war period, but remained within the Class I limits.

According to the current regulation (4), the assessment of spatio-temporal variations should take into account $90^{\text {th }}$ percentiles of a particular parameter, as they may point to outstanding events that occurred at a particular moment.

We found that the $90^{\text {th }}$ percentile of EC also increased in the post-war period, but the medians do not indicate any significant variation between the three sites over the monitored 24 years.

To get a better insight in the water quality, we also analysed total suspended solids (TSS). We found that TSS median values dropped in the post-war period and show a higher variability between the three sampling sites. TSS often points to intense anthropogenic activity along the river. It may involve sanitary and industrial wastewater, runoff from streets that can bring solids, debris, human waste, and other solid material into the river. Our results are supported by earlier findings (28), which have shown that the Drava River bed and floodplain sediments consist of sand, mud, and gravelly sand. In addition, sand and gravel are exploited from the river bed of the Drava in a number of places (29), which can result in sudden variations of total suspended solids at any time of the year.

A large part of our study deals with the paremeters that refer to water oxigenation. Although dissolved oxygen (DO) is essential for aquatic organisms, both deficiency and extremely high levels indicate an unhealthy river. We used the $10^{\text {th }}$ percentile of DO and OS, as it points to outstanding events in water oxygen deficiency (4). Our results show that DO and OS do not indicate any spatial or temporal pattern.

$\mathrm{BOD}_{5}$ and $\mathrm{COD}$ are other important parameters that point to the oxygen regime in the river water. Both refer to biochemical reactions in natural waterways, which contain bacteria and nutrients. While COD test measures the oxygen demand of oxidizable pollutants, the $\mathrm{BOD}_{5}$ test measures the oxygen demand of biochemically degradable organic matter present in water. In our study COD values generally dropped compared to the pre-war period.

A drop in organic pollution during the two observed periods is probably associated with lower post-war industrial and agricultural activity,.

The DO, OS, and COD values suggest that the oxygen regime in the Drava River water is relatively favourable, and its water belongs to Class II.

In contrast, $\mathrm{BOD}_{5}$ was noticeably higher in the post-war period (Figure 2). BOD is used to establish self-purification of surface waters, and indicates water load with dissolved organic matter. Contributors to this load with oxygen-depleting substances include food, pulp and paper production, sugar beet processing, discharge of poorly treated industrial waste, landfill leachate, agricultural effluents, wetlands and riparian vegetation (30). The Drava comes to Croatia highly polluted with organic matter (12) (Class IV by Croatian standards). The Lower Drava receives poorly treated wastewaters from a number of Croatian and Hungarian towns (31) and even though it does not follow the $\mathrm{BOD}_{5}$ lowering trends observed in other European rivers $(7,10)$, it seems to reaerate pretty well.

In this study, we also evaluated the concentrations of nitrite nitrogen $\left(\mathrm{NO}_{2}-\mathrm{N}\right)$ that were in the range of Class II, according to the current regulations (4). Nitrite nitrogen concentrations in freshwaters are usually low, $0.01 \mathrm{mg} \mathrm{L}^{-1}$, and higher values are indicative of industrial effluents. Nitrites appear as intermediaries in the nitrogen cycle; they are unstable and can transform into nitrates or ammonia (32).

Nitrate concentrations in water seldom exceed 0.1 $\mathrm{mg} \mathrm{L}^{-1}$ of $\mathrm{NO}_{3}-\mathrm{N}$. Incerased levels of nitrates usualy point tocontamination by the inappropriate disposal of human and industrial waste, or the use of nitrogenated fertilisers in agriculture (27). Our results (Figure 3) show a decreasing post-war trend, which may suggest lower agricultural activity. The level of nitrate nitrogen in this study was lower than in other 
European rivers (10), about the same as in the Danube (8), and higher than in the Sava River (7).

Unpolluted waters usually contain small concentrations of ammonia $\left(<0.1 \mathrm{mg} \mathrm{L}^{-1}\right.$ of $\left.\mathrm{NH}_{4}-\mathrm{N}\right)$ (32). Increased ammonium often indicates discharge of untreated domestic wastewaters (32-34). In our study, the levels of ammonia-nitrogen $\left(\mathrm{NH}_{4}-\mathrm{N}\right)$ showed a clear decreasing trend (from $0.3 \mathrm{mg} \mathrm{L}^{-1}$ to $0.1 \mathrm{mg} \mathrm{L}^{-1}$ ) between the pre- and post-war periods and are lower than in other European rivers (10). However, site Nemetin showed much higher values in the postwar period (Figure 4), which may point to pollution from Osijek wastewaters.

Nitrogen in river waters may provide information about pollution. Since $\mathrm{NH}_{4}-\mathrm{N}$ is one of the first steps in organic matter decomposition, higher $\mathrm{NH}_{4}-\mathrm{N}$ points to recent pollution, while elevated levels of nitrite and nitrate point to more remote contamination..

Based on the results shown in Figure 4 it seems that wastewater in Osijek greatly affects the quality of water at the sampling site 3 located a few kilometres downstream. The median concentration of $\mathrm{NH}_{4}-\mathrm{N}$ between the two observed periods dropped from 0.3 $\mathrm{mg} \mathrm{L}^{-1}$ to $0.1 \mathrm{mg} \mathrm{L}^{-1}$, which is still a lower value compared to other European rivers $\left(0.8 \mathrm{mg} \mathrm{L}^{-1}\right.$ to 0.3 $\left.\mathrm{mg} \mathrm{L}^{-1}\right)(10)$.

Based on the values of $\mathrm{NO}_{2}-\mathrm{N}$, we can conclude that that the Drava river waters are still within the guideline values for Class II. However, based on the $90^{\text {th }}$ percentiles of $\mathrm{NH}_{4}-\mathrm{N}$ and $\mathrm{NO}_{3}-\mathrm{N}$, it exceeds recommended limits for Class II (4).

Microbiological parameters evaluated in this study point to a slight deteritoriation of river water quality in the post-war period. Figure 5 shows that total coliform bacteria slightly decreased in the post-war period. An exception is the sampling site 3 (Nemetin), where the $90^{\text {th }}$ percentile value was alarmingly higher than at the other sites. Bacterial contamination at this sampling site is mostly caused by domestic sewage from sanitary and industrial wastewater discharges and urban runoff from city streets and surrounding areas.

Measurements of heterotrophic bacteria (Figure 6) clearly confirm a significant deterioration in bacterial water quality downstream of Osijek. This noticeable deterioration is a consequence of inadequate waste water treatment (31).

The results of descriptive statistics are further confirmed by the cluster analysis, which outlined a lack of correlation between total coliform bacteria obtained at the three sampling sites. Taken together, these results indicate that microbiological contamination is a local (urban) and not a regional or transboundary problem. Therefore, urban wastewaters have a significant influence on the microbiological composition of the Drava River water.

The overall analysis (see Figures 2-6) suggests that some parameters increased at all locations in the postwar period, which is illustrated by longer upper whiskers. This can be a result of both natural variations and accidents, such as a floods, storm waters, or discharge of manure (10).

The Drava River water quality has improved over the 24 years of measurement. However, biological oxygen demand all along the lower Drava and microbiological contamination downstream of Osijek raise concern about urban and industrial wastewater treatment and discharges.

The task at hand of the national and local authorities is to ensure that the Drava meets all Class II requirements for safe human use and consumption. The results of our study point out the specific parameters that need to be addressed in future preventive activities against pollution.

\section{REFERENCES}

1. Maričić S, Mijušković-Svetinović T. Lower Drava monitoring. In: Gayer J, Scheuerlein K, Starosolszky O, editors. Proceedings of International Conference on European River development ICERD; 16-18 Apr 1998; Budapest, Hungary. Budapest: Water Resources Research Centre Plc.; 1998. p. 301-8.

2. Habuda-Stanić M, Kuleš M, Kalajdžić B, Romić Ž. Quality of groundwater in eastern Croatia. The problem of asenic pollution. Desalination 2007;210:157-62.

3. Romić Ž, Habuda-Stanić M, Kalajdžić B, Kuleš M. Arsenic distribution, concentration and speciation in groundwater of the Osijek area, eastern Croatia. Appl Geochem 2011;26:3744.

4. Uredba o klasifikaciji voda [Regulation on water classification, in Croatian]. Narodne novine 1998/77.

5. Državni plan za zaštitu voda [State plan on water protection, in Croatian]. Narodne novine 1999/8.

6. Brodnjak-Vončina D, Dobčnik D, Novič M, Zupan J. Chemometrics characterisation of the quality of river water. Anal Chim Acta 2002;462:87-100.

7. Živadinović I, Olijević K, Gržetić I, Popović A. Long-term changes in eco-chemical status of the Danube River in the region of Serbia. J Serb Chem Soc 2010;75:1125-48.

8. Čađo S, Miletić A, Dopuđa-Glišić T, Denić Lj. Physicalchemical characteristics and phytoplankton composition of the Sava River on its lower flow stretch through Serbia. In: Proceedings $36^{\text {th }}$ International Conference of IAD; 4-8 Sep 2006; Vienna-Klosterneuburg, Austria. Vienna: Austrian Committee Danube Research; 2006. p.184-8. 
9. Dragun Z, Raspor B, Roje V. The labile metal concentrations in Sava River water assessed by diffusive gradients in thin films. Chem Spec Bioavailab 2008;1:33-46.

10. European Environment Agency. Oxygen consuming substances in river [displayed 20 September 2011]. Available at http://www.eea.europa.eu/data-and-maps/indicators/ oxygen-consuming-substances-in-rivers

11. Vuković Ž, Marković Lj., Radenković M, Vuković D, Stanković S. Heavy metal and bacterial pollution of the Sava River in Serbia. Arh Hig Rada Toksikol 2011;62:11-6.

12. Vitale K, Marijanović-Rajčić M, Senta A. Waters in Croatia between practice and needs: public health challenge. Croat Med J 2002;43:485-92.

13. ISO 10304-1:2007; EN ISO 10304-1:2009(E). Water quality - Determination of dissolved anions by liquid chromatography of ions - Part 1: Determination of bromide, fluoride, nitrate, nitrite, phosphate and sulphate. International organisation for standardization/Technical Committee ISO/TC 147/ Switzerland.

14. ISO 14911:1998; EN ISO 14911:1999. Water quality Determination of dissolved $\mathrm{Li}^{+}, \mathrm{Na}^{+}, \mathrm{NH}_{4}^{+}, \mathrm{K}^{+}, \mathrm{Mn}^{2+}, \mathrm{Sr}^{2+}$, $\mathrm{Ba}^{2+}$, using ion chromatography - Method for water and waste water. International organisation for standardization/ Technical Committee ISO/TC 147/Switzerland.

15. ISO 5815-2:2003. Water quality - Determination of biochemical oxygen demand after $\mathrm{n}$ days (BODn) Part 2. Method for undiluted samples. International organisation for standardization/Technical Committee ISO/TC 147/ Switzerland.

16. ISO 8467:1993; EN ISO 8467:1995(E). Water quality Determination of permanganate index. International organisation for standardization/Technical Committee ISO/ TC 147/Switzerland.

17. DIN 38409-2:1987-03. German standard for the examination of water, waste water and sludge; parameters characterizing effects and substances (Group H2); determination of filterable matter and the residue on ignition (H 2). Deutsches Institut für Normung E.V. Deutschland.

18. ISO 5814:1990. Water quality - Determination of dissolved oxygen - Electrochemical probe method. International organisation for standardization/Technical Committee ISO/ TC 147/Switzerland.

19. ISO 5814:1990. Water quality - Determination of dissolved oxygen - Electrochemical probe method. International organisation for standardization/Technical Committee ISO/ TC 147/Switzerland

20. ISO 7888:1985; EN 27888:1993(E). Water quality Determination of electric water quality - Determination of electrical conductivity. International organisation for standardization/Technical Committee ISO/TC 147/ Switzerland.

21. ISO 10523:2008(E). Water quality - Determination of $\mathrm{pH}$. International organisation for standardization/Technical Committee ISO/TC 147/Switzerland.
22. ISO 9308-1:2000/Cor 1:2007. EN ISO 9308-1:2000/ AC:2008. Water quality - Detection and enumeration of Escherichia coli and coliform bacteria - Part 1. Membrane filtration method. International organisation for standardization/Technical Committee ISO/TC 147/ Switzerland.

23. ISO 6222:2000; EN ISO 6222:1999. Water quality Enumeration of culturable micro-organisms - Colony count by inoculation in nutrient agar culture medium. International organisation for standardization/Technical Committee ISO/ TC 147/Switzerland.

24. Mendiguchía C, Moreno C, Galindo-Riaño MD, GarciaVargas M. Using chemometric tools to assess anthropogenic effects in river water. A case study: Guadalquivir River (Spain). Anal Chim Acta 2004;515:143-9.

25. Massart DL, Vandeginste BGM, Buydens LMC, De Jong S, Lewi PJ, Smeyers-Verbeke J. Handbook of Chemometrics and Qualimetrics, Part B. Amsterdam: Elsevier; 1998.

26. Bouza-Deaño R, Ternero-Rodriguez M, Fernández-Espinosa AJ. Trend study and assesment of surface water quality in the Ebro River (Spain). J Hydrol 2008;361:227-39.

27. World Health Organisation (WHO). Water Quality Assessments - A Guide to Use of Biota, Sediments and Water in Environmental Monitoring - Second Edition [displayed 20 September 2011]. Available at http://www.who.int/water sanitation_health/resourcesquality/watqualassess.pdf

28. Halamić J, Galović L, Šparica M. Heavy metal (As, Cd, Cu, $\mathrm{Hg}, \mathrm{Pb}$ and $\mathrm{Zn}$ ) distribution in topsoil developed on alluvial sediments of the Drava and Sava rivers in NW Croatia. Geol Croat 2003;56:215-32.

29. Romić M, Romić D. Heavy metals distribution in agricultural topsoils in urban area. Environ Geol 2003;43:795-805.

30. Stringfellow WT, Hanlon JS, Borglin ES, Quinn NWT. Comparison of wetland and agriculture drainage as sources of biochemical oxygen demand to the San Joaquin River, California. Agric Water Management 2008;95:527-38.

31. Miljušković-Svetinović T, Maričić $S$, Tušar B. The wastewater of the city of Osijek. In: Bednarczyk S, Szymkiewicz R, Suligowski Z, editors. Proceedings of the VII International Symposium on Water Management and Hydraulic Engineering; 10-12 Sep 2001. Miedzybrodzie Zywieckie, Poland. Gdansk: Faculty of Hydro and Environmental Engineering, Technical University of Gdansk; 2001. p. 336-42.

32. Michalski R, Kurzyca I. Determination of nitrogen species (nitrate, nitrite and ammonia ions) in environmental samples by ion chromatography. Pol J Environ Stud 2006;1:5-18.

33. Coletti C, Testezlaf R, Ribeiro TAP, Souza RTG, Pereira DA. Water quality index using multivariate factorial analysis. Rev Bras Eng Ageic Ambient 2010;14:517-22.

34. Milovanović M. Water quality assessment and determination of pollution sources along the Axios/Vardar River, southeastern Europe. Desalination 2007;213:159-73. 


\section{Sažetak}

\section{PROMJENE U KVALITETI VODE RIJEKE DRAVE PRIJE I POSLIJE DOMOVINSKOGA RATA}

Cilj ovoga rada bio je procijeniti kvalitetu vode rijeke Drave, klasificirati je i utvrditi postojanje prostornih i vremenskih promjena tijekom perioda od 24 godine. Analizirali smo 13 fizikalno-kemijskih i mikrobioloških parametara vode rijeke Drave na tri mjerne postaje smještene na području donjeg toka Drave (istočna Hrvatska) tijekom dvaju različitih razdoblja: 1985.-1992. (period prije rata) i 1993.-2008. (period poslije rata). Iako su vrijednosti većine podataka prikupljenih tijekom dvaju promatranih razdoblja oscilirale, vrijednosti su im se još uvijek nalazile u granicama za I. i II. vrstu voda. Vrijednosti nekih fizikalno-kemijskih varijabla, kao što $\mathrm{su} \mathrm{NO}_{3}-\mathrm{N}, \mathrm{NH}_{4}-\mathrm{N}$ i BPK 5 još su uvijek iznad granice za II. vrstu. Rezultati ovog istraživanja pokazali su blago organsko onečišćenje vode rijeke Drave s visokim koncentracijama otopljenog kisika. Povećanje broja ukupnih koliformnih i heterotrofnih bakterija u poslijeratnom razdoblju veliki je problem u području nizvodno od Osijeka pri čemu njihov broj katkad dostiže i vrijednosti za V. skupinu površinskih voda. Rezultati analize kvalitete vode rijeke Drave u dva različita razdoblja na dva mjerna mjesta uzvodno od Osijeka upućuju na tendenciju poboljšanja, iako neki od promatranih parametara pokazuju vrijednosti više od onih za II. skupinu riječnih voda. Različitosti, odnosno sličnosti među mjernim postajama istražene su metodom klasterske analize.

KLJUČNE RIJEČI: fizikalno-kemijski parametri, klasterska analiza, mikrobiološki parametri, organsko zagađenje, riječna voda

\section{CORRESPONDING AUTHOR:}

Vlatka Gvozdić

Department of Chemistry

J.J. Strossmayer University

F. Kuhača 20, 31000 Osijek, Croatia

E-mail:vlatka.gvozdic@kemija.unios.hr 